\title{
Effect of High Intensity Interval Training versus Circuit Weight Training on Glycated Hemoglobin in Type 2 Diabetic Patients
}

\author{
RANA A. ABD EL-FATTAH, M.Sc.*; NAGWA M. HAMED, Ph.D.*; \\ ABEER A. ABD EL-HAMEED, Ph.D.*; HEBA A. ABD EL-GHAFAR, Ph.D.* and LAILA A. RASHED, M.D.** \\ The Department of Physical Therapy for Cardiovascular/Respiratory Disorder and Geriatrics Disorders, \\ Faculty of Physical Therapy* and The Department of Medical Biochemistry \& Molecular Biology, Faculty of Medicine**, \\ Cairo University**
}

\begin{abstract}
Background: Diabetes is a fast-grwoing health problem in Egypt with a significant impact on morbidity, mortality, and health care resources. While increasing physical activity is an essential component of all effective lifestyle-based trials for the prevention of type $2 \mathrm{DM}$.

Aim of Study: To compare between high intensity interval training and circuit weight training on type 2 DM.

Material and Methods: Sixty participants had participated in this study. Their ages ranged from forty to fifty years men were selected from Manshyet El-Bakry Hospital. Group (A): Consisted of 30 patients received high intensity interval training program 3 sessions/week for 12 weeks training consisted of interval at high intensity training (85-90\% of $\left.\mathrm{HR}_{\max }\right)$ and recovery at (50-70\% of HRmax) $_{\text {Group (B): }}$ Thirty men participated in this group, received circuit weight training exercises performed for 3 sessions/week for 12 weeks. the resistance (weight) $30 \%$ to $40 \%$ of 1 repetition maximum for upper body and $50 \%$ to $60 \%$ for lower-body exercises. Each participant had undergone Measurments for Fasting Blood Glucose, Glycated Hemoglobin $\left(\mathrm{HbA}_{1_{\mathrm{c}}}\right)$ and 6MWT before and after study.
\end{abstract}

Results: The results of this study revealed that there was significant reduction in FBG by $17.68 \%$ and $14.18 \%$ in group $\mathrm{A}$ and group $\mathrm{B}$ respectively. While the results of $\mathrm{HbAlc}_{1 \mathrm{c}}$ there was reduction by $20.77 \%$ and $13.37 \%$ in group A and group B. There was increase in 6MWT by $10.28 \%$ and $4.54 \%$ in group A and B respectively. $(p<0.05)$.

Conclusion: Within the limitation of the current study it was concluded that both types of exercises significantly improve $\mathrm{HBA} l_{c}$, fasting blood glucose and 6 minute walk distance after 12 weeks of training in favour of high intensity interval training.

Key Words: Diabetes mellitus - High intensity interval training - Circuit weight training.

Correspondence to: Dr. Rana A. Abd El-Fattah, The Department of Physical Therapy for Cardiovascular/ Respiratory Disorder and Geriatrics Disorders, Faculty of Physical Therapy, Cairo University

\section{Introduction}

DIABETES is a complex, chronic illness requiring continuous medical care with multifactorial riskreduction strategies beyond glycemic control. Ongoing patient self-management education and support are critical to preventing acute complications and reducing the risk of long-term complications. Significant evidence exists that supports a range of interventions to improve diabetes outcomes [1].

Increased physical activity is an essential component of all effective lifestyle-based trials for the prevention of T2DM. Prospective evidence has shown that both aerobic exercise and resistance training independently have beneficial effect [2]

The most common reason for not engaging in physical activity is lack of time. Since 2014, the American College of Sports Medicine (ACSM) has been consistently recommending High-Intensity Interval Training (HIIT) as the most effective and time-efficient form of exercise [3]. High-Intensity Interval Training (HIIT), also called High-Intensity Intermittent Exercise (HIIE) or Sprint Interval Training (SIT), is a form of interval training, a strategy alternating short periods of intense anaerobic using a (90-100\%) of $\mathrm{HR}_{\max }$. Less intense recovery periods, until too exhausted to continue [4].

Circuit training programs offer the combination of aerobic and resistance exercises, the intensity of which can be adapted to the individual participant and program purpose. In circuit training, participants move continuously between exercise types with only short breaks. Thus, circuit training has been reported as an interesting and effective way 
to simultaneously develop both the muscular and cardiovascular systems [5].

\section{Material and Methods}

The study was carried out on sixtymen suffering from type 2 diabetes mellitus, their ages ranged from 40-50, their BMI ranged between 20 to 39.9 $\mathrm{kg} / \mathrm{m}^{2}$, their fasting blood glucose ranged from $126-160 \mathrm{mg} / \mathrm{dl}$. They were selected from Manshyet El-Bakry Hospital, Egypt from March to December 2019 on the following criteria. They were randomly divided into two equal groups (in numbers).

Study design: Compartivestudy. All particpants were assigned randomly into two equal groups in numbers.

Ethical consideration: The study has been approved by Ethical Committee in Faculty of Physical Therapy, Cairo University.

Informed consent form was taken from every patient.

\section{Procedure:}

\section{A- Evaluation:}

-A blood sample was taken for testing Glycosylated hemoglobin and fasting blood glucose before and after 12 weeks by using centrifuge.

- Functional capacity was examined by:

The six minute walking test (6MWT).

The 6MWT is a standardized performancebased test of functional exercise capacity and is important because it most closely represents activities of daily living [6].

The 6-Minute-Walk Test (6MWT) was performed indoors, along a long, flat, straight, enclosed corridor with a hard surface. The walking was $30 \mathrm{~m}$ (100 feet) in length. The participants were instructed to walk as far as possible for $6 \mathrm{~min}$ in a $30-\mathrm{m}$ hallway and were given standardized verbal encouragement every minute. 6MWDs were recorded in meters [7].

Reasons for immediately stopping a 6MWT include chest pain, intolerable dyspnea, leg cramps, staggering and pale or ashen appearance. If the test was stopped for any of these reasons, the patient should sit immediately [6].

\section{B- Treatment:}

- Group (A): Consisted of 30 patients received high intensity interval training program walking on treadmail. For 3 days/week (day another day) for 12 weeks. Training consisted of interval at high intensity training (85-90\% of $\mathrm{HR}_{\max }$ and

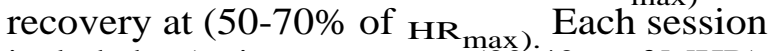
included a 5 minute warm up (30-40\% of MHR) and a 5 minute cool down (30-40\% of MHR).

They were trained using heart rate range or reserve method (Karvonen's method).

The Karvonen formula: Training HR $=$ Rest $\mathrm{HR}+\%\left(\mathrm{HR}_{\max }-\right.$ rest $\left.\mathrm{HR}\right)[8]$ and the $\mathbf{H R}_{\max }$ was estimated using the formula 220-age [9].

Training was applied in the form of 6 bouts of 1 min interval training at high intensity interval training 80 to $95 \%$ of peak heart rate [10]. Separated by $4 \mathrm{~min}$ of active recovery period at (50-70\% of $\mathrm{HR}_{\max }$ ). Training intensity was controlled using borg scale (scale 6-20), aiming at a Borg score 1517 during high intensity interval training [11].

The patient should not exceed his training heart rate during exercise period. The training heart rate increased gradually according to each patient's response during exercise training session, starting with $55 \%$ of peak heart rate, till reached $95 \%$ at the end of 12 weeks.

- Goup (B): Consisted of 30 patients received circuit weight training 3 days per week with resistance (weight) $30 \%$ to $40 \%$ of 1 repetition maximum for upper body and $50 \%$ to $60 \%$ for lower-body exercises. One repetition maximum is the highest weight lifted 1 time [12].

Each session with 10-15 repetitions for 2-3 sets. The CWT involved the big muscles of upper limb, lower limb and abdominal muscles included knee extensors, knee flexors, hip abductors and aductors, elbow flexors, elblow extensors and abdominal muscles using sandbags and free weights.

The progression by decreasing rest time between each set and gradually increase number of repetitions once $10-15$ repetitions can be performed.

\section{Results}

\section{General characteristics of the subjects:}

- Group A: Thirty male patients with type II diabetes were included in this group. Their mean \pm SD age and BMI were $44.76 \pm 2.94$ years and $28.8 \pm 2.7 \mathrm{~kg} / \mathrm{m}^{2}$ respectively Figs. $(1,2)$.

- Group B: Thirty male patients with type II diabetes were included in this group. Their mean \pm SD age and BMI were $45.6 \pm 3.04$ years and 28.06 $\pm 3.52 \mathrm{~kg} / \mathrm{m}^{2}$ respectively (Table 3 ). 
Comparing the general characteristics of the subjects of both groups revealed that there was no significance difference between both groups in the mean age and BMI $(p>0.05)$.

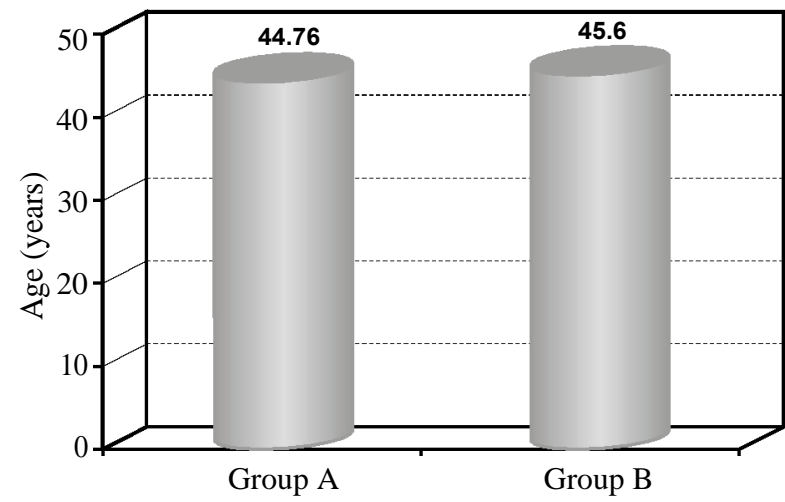

Fig. (1): Mean age of group A and B.

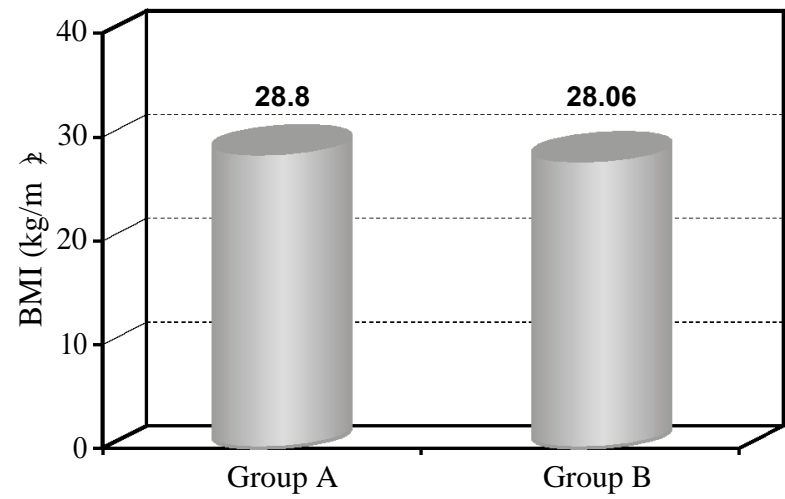

Fig. (2): Mean BMI of group A and B.

Fasting blood glucose:

I- Between groups comparison (inter group comparison):

Pre-treatment, the mean \pm SD FBG pre treatment of the group A was $138.76 \pm 11.96 \mathrm{mg} / \mathrm{dl}$ and that of the group B was $136.63 \pm 10.56 \mathrm{mg} / \mathrm{dl}$. The mean difference between both groups was 2.13 $\mathrm{mg} / \mathrm{dl}$. There was no significant difference in FBG between the group A and B pre-treatment $(p=0.46)$. (Table 1), Fig. (3).

Table (1): Comparison of pre and post-treatment mean values of FBG between group A and B.

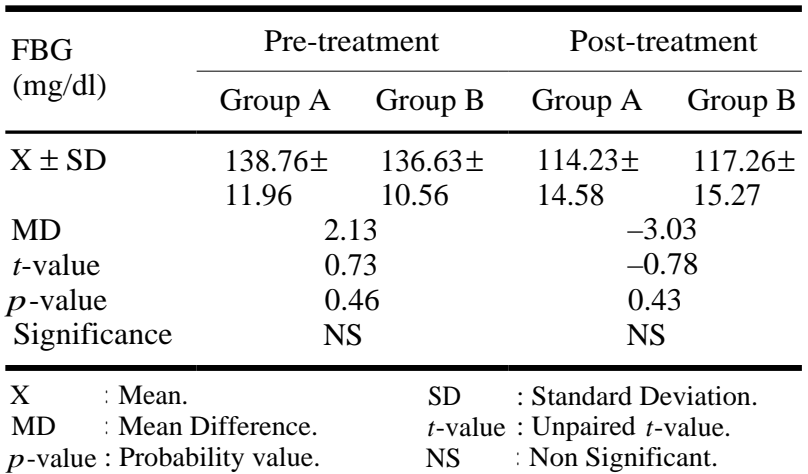

Post-treatment, the mean \pm SD FBG post treatment of the group A was $114.23 \pm 14.58 \mathrm{mg} / \mathrm{dl}$ and that of the group B was $117.26 \pm 15.27 \mathrm{mg} / \mathrm{dl}$. The mean difference between both groups was 3.03 $\mathrm{mg} / \mathrm{dl}$. There was no significant difference in FBG between the group A and B post-treatment ( $p=0.43$ ) (Table 1).

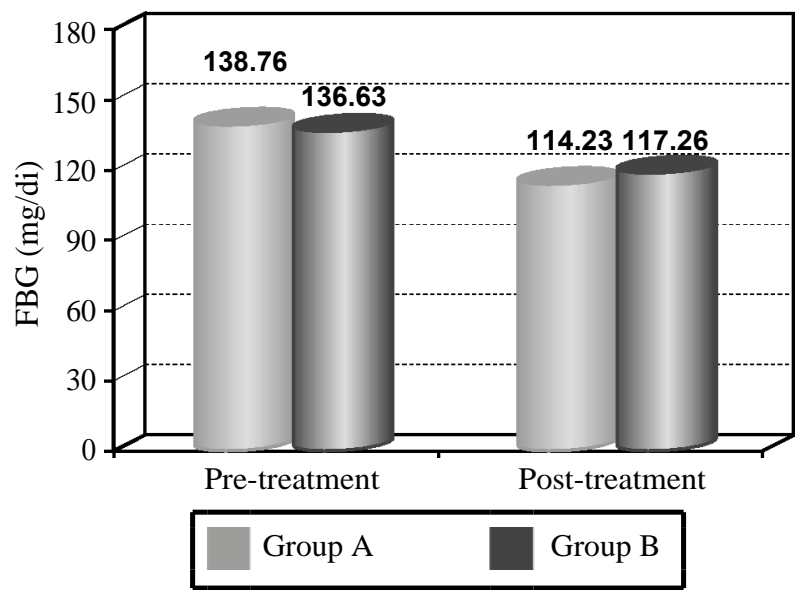

Fig. (3): Mean values of FBG of the group A and B at pre and post-treatment

Glycated Hemoglobin $\left(\mathrm{HbA}_{\mathrm{l}_{c}}\right)$ :

\section{I- Between groups comparison (inter group com- parison):}

Pre-treatment, the mean $\pm \mathrm{SD} \mathrm{HbA}_{1 \mathrm{c}}$ pre treatment of the group A was $8.86 \pm 1.3 \%$ and that of the group B was $8.75 \pm 1.05 \%$. The mean difference between both groups was $0.11 \%$. There was no significant difference in $\mathrm{HbA}_{1 \mathrm{c}}$ between the group $\mathrm{A}$ and $\mathrm{B}$ pre-treatment $(p=0.72)$.

Post-treatment, the mean \pm SD HbA $_{1 c}$ posttreatment of the group A was $7.02 \pm 0.91 \%$ and that of the group was $7.58 \pm 0.82 \%$. The mean difference between both groups was $-0.56 \%$. There was a significant decrease in $\mathrm{HbA}_{1 \mathrm{c}}$ of the group A compared with that of the group B post-treatment ( $p=$ $0.01)$.

Table (2): Comparison of pre and post-treatment mean values of $\mathrm{HbA} 1 \mathrm{c}_{\mathrm{c}}$ between group $\mathrm{A}$ and $\mathrm{B}$

\begin{tabular}{|c|c|c|c|c|}
\hline \multirow{2}{*}{$\mathrm{HbA}_{1 \mathrm{c}}(\%)$} & \multicolumn{2}{|c|}{ Pre-treatment } & \multicolumn{2}{|c|}{ Post-treatment } \\
\hline & Group A & Group B & Group A & Group B \\
\hline $\mathrm{X} \pm \mathrm{SD}$ & $8.86 \pm 1.3$ & $8.75 \pm 1.05$ & $7.02 \pm 0.91$ & $7.58 \pm 0.82$ \\
\hline MD & \multicolumn{2}{|c|}{0.11} & \multicolumn{2}{|c|}{-0.56} \\
\hline$t$-value & \multicolumn{2}{|c|}{0.35} & \multicolumn{2}{|c|}{-2.47} \\
\hline$p$-value & \multicolumn{2}{|c|}{0.72} & \multicolumn{2}{|c|}{0.01} \\
\hline Significance & \multicolumn{2}{|c|}{ NS } & \multicolumn{2}{|l|}{$S$} \\
\hline 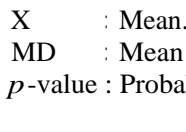 & $\begin{array}{l}\text { Difference. } \\
\text { ility value. }\end{array}$ & $\begin{array}{l}\text { SD } \\
t \text {-value } \\
\text { NS } \\
\text { S }\end{array}$ & $\begin{array}{l}\text { : Standard } \\
\text { : Unpaired } \\
\text { : Non Sign } \\
\text { : Significan }\end{array}$ & $\begin{array}{l}\text { eviation. } \\
\text { value. } \\
\text { icant. }\end{array}$ \\
\hline
\end{tabular}




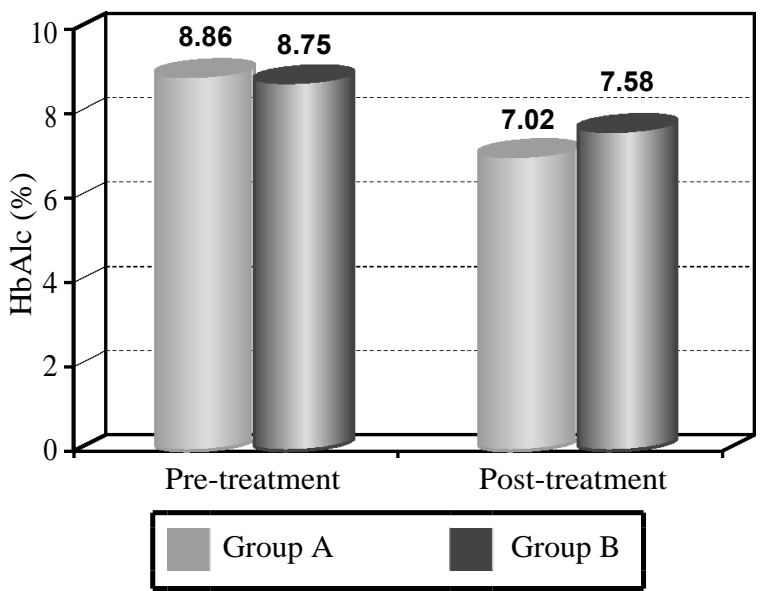

Fig. (4): Mean values of ${ }_{\mathrm{HbA} 1 \mathrm{c}}$ of the group A and B at pre and post-treatment.

\section{Minute Walk test:}

I- Between groups comparison (inter group comparison):

Pre-treatment, the mean \pm SD $6 \mathrm{MWD}$ pre treatment of the group A was $371.16 \pm 40.4 \mathrm{~m}$ and that of the group B was $368.8 \pm 36.21 \mathrm{~m}$. The mean difference between both groups was $2.36 \mathrm{~m}$. There was no significant difference in 6MWD between the group A and B pre-treatment $(p=0.81)$.

Table (3): Comparison of pre and post-treatment mean values of 6MWD between group A and B.

\begin{tabular}{|c|c|c|c|c|}
\hline \multirow{2}{*}{ 6MWD (m) } & \multicolumn{2}{|c|}{ Pre-treatment } & \multicolumn{2}{|c|}{ Post-treatment } \\
\hline & Group A & Group B & Group A & Group B \\
\hline $\mathrm{X} \pm \mathrm{SD}$ & $\begin{array}{l}371.16 \pm \\
40.4\end{array}$ & $\begin{array}{l}368.8 \pm \\
36.21\end{array}$ & $\begin{array}{l}409.3 \pm \\
38.52\end{array}$ & $\begin{array}{l}385.53 \pm \\
42.71\end{array}$ \\
\hline $\begin{array}{l}\text { MD } \\
t \text {-value } \\
p \text {-value } \\
\text { Significance }\end{array}$ & $\begin{array}{l}2 \\
0 \\
0 \\
1\end{array}$ & & $\begin{array}{l}2 \\
2 . \\
0 . \\
S\end{array}$ & \\
\hline $\begin{array}{l:l}\mathrm{X} & \text { Mean } \\
\mathrm{MD} & \text { Mean } \\
p \text {-value } & \text { Prob }\end{array}$ & $\begin{array}{l}\text { fference. } \\
\text { ty value. }\end{array}$ & $\begin{array}{l}\text { SD } \\
t \text {-value } \\
\mathrm{NS} \\
\mathrm{S}\end{array}$ & $\begin{array}{l}\text { : Standard I } \\
\text { Unpaired } \\
\text { : Non Signi } \\
\text { : Significan }\end{array}$ & $\begin{array}{l}\text { viation. } \\
\text { alue. } \\
\text { ant. }\end{array}$ \\
\hline
\end{tabular}

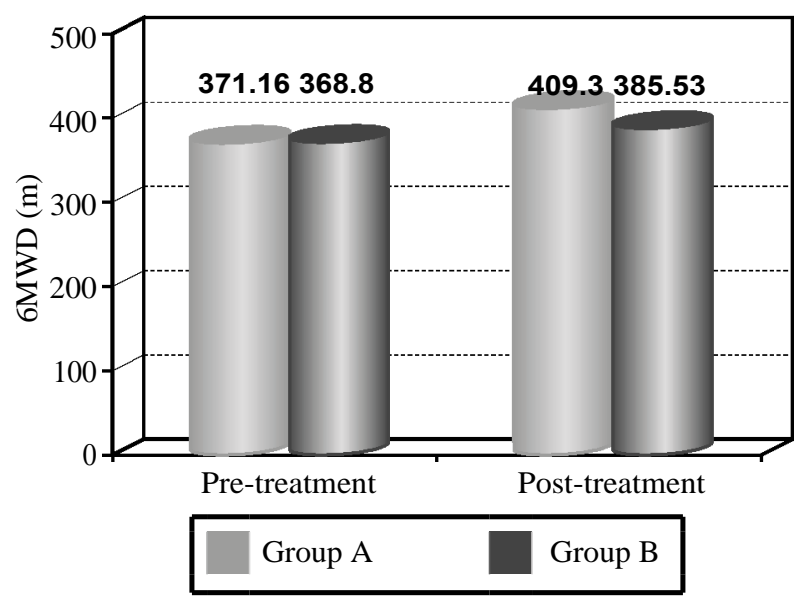

Fig. (5): Mean values of $6 \mathrm{MWD}$ of the group A and B at pre and post-treatment.
Post-treatment, the mean \pm SD 6 MWD posttreatment of the group A was $409.3 \pm 38.52 \mathrm{~m}$ and that of the group B was $385.53 \pm 42.71 \mathrm{~m}$. The mean difference between both groups was $23.77 \mathrm{~m}$. There was a significant increase in 6MWD of the group A compared with that of the group B post-treatment $(p=0.02)$.

\section{Discussion}

Diabetes is a group of metabolic diseases characterized by hyperglycemia resulting from defects in insulin secretion, insulin action, or both. The chronic hyperglycemia of diabetes is associated with long-term damage, dysfunction, and failure of different organs, especially the eyes, kidneys, nerves, heart, and blood vessels [13] and for many years, physical activity has been along with diet and medication considered fundamental in the treatment of diabetes. The primary objective of this study was to compare between the therapeutic efficacy of high intensity interval training and ciruit weigh training on glycated hemoglobin in type 2 diabetic patients. This study was conducted on 60 diabetic men with Type 2 Diabetes Mellitus who agreed to participate in the study, their ages ranged from 40 to 50 years, and were selected randomly from Manshyet El-Bakry Hospital to participate in this study.

All patients were controlled type 2 diabetes with fasting blood glucose ranged from (126-160) $\mathrm{mg} / \mathrm{dl}$. They were divided into two groups: The first group, group (A): Consisted of 30 men, their ages ranged from 40 to 50 years with mean of $(44.76 \pm 2.94)$ years. Also their body mass index $>20 \mathrm{~kg} / \mathrm{m}^{2}$. With mean of $(28.8 \pm 2.7) \mathrm{kg} / \mathrm{m}^{2}$. They underwent a high intensity interval training program, performed 3 times per week for 12 weeks. The second group, group (B): Consisted of 30 men, their ages ranged from 40 to 50 years with mean of (45.6 \pm 3.04 )years. Their body mass index $>20$ $\mathrm{kg} / \mathrm{m}^{2}$ with mean of $\left(28.06 \pm 3.52 \mathrm{~kg} / \mathrm{m}^{2}\right)$. They were enrolled in a resisted training three times per week for 12 weeks. The measured in this study were FBG, $\mathrm{HbA}_{1 \mathrm{c}}$ and 6 Minute Walk Test (6MWT). In which its results showed clearly that both HIIT program and Circuit Weight Training (CWT) have a positive effect on glycatedhemoglobin in type 2 diabetic patients. Also results revealed that, the results of this study revealed that there was significant reduction in FBG by $17.68 \%$ and $14.18 \%$ in group A and group B respectively. While the results of $\mathrm{HbA}_{1 \mathrm{c}}$ there was reduction by $20.77 \%$ and $13.37 \%$ in group A and group B. There was increase in 6MWT by $10.28 \%$ and $4.54 \%$ in group $A$ and $B$ respectively. 
The researches supported the results of this study in parameters used $\mathrm{HbA}_{1_{\mathrm{c}}}$, FBG and 6MWD as shown.

Stoa et al., [14] had found that people with T2D who performed a supervised HIIT program at an intensity of $85-95 \%$ of their maximal heart rate with $52 \% \mathrm{vO}_{2 \text { peak }}$ interval experienced a significant increase in $\mathrm{VO}_{2 \text { peak }}$ and a reduction in hemoglobin $\mathrm{A}_{1_{\mathrm{c}}}\left(\mathrm{HbA}_{1_{\mathrm{c}}}\right)$, body weight, and Body Mass Index (BMI).

Mitranun et al., [15] also found that HIIT improved $\mathrm{HbA}_{l_{\mathrm{c}}}$, maximal aerobic capacity, and other cardiovascular risk factors in T2D patients, even if the total exercise time was reduced to half of that recommended.

Richards et al., [16] showed that using the hyperinsulinemiceuglycemic clamp technique, insulin sensitivity was improved $72 \mathrm{~h}$ following a 2 -week SIT intervention in healthy men and women.

Hood et al., [17] who conductedthat six sessions of HIIT over 2 weeks improved insulin sensitivity based on fasting measures of glucose and insulin in previously sedentary individuals. Using Continuous Glucose Monitoring (CGM).

In another study, Shaban et al., [18] assessed an even lower-volume HIIT protocol involving $4 \mathrm{X}$ 30 seconds at $\sim 100 \%$ of maximal aerobic capacity with 4-minute rest periods in nine patients with type 2 diabetes. Bloodglucosewasreduced immediately after each session, the authors noted that six of the nine participants did see improvements in insulin resistance assessed by fasting homeostasis model assessment scores and argued that this HIIT protocol may be effective for improving metabolic control.

As reported by Boutcher, [19] all studies that have assessed insulin response to HIIT recorded significant improvements of between a 23 and a $58 \%$ increase in insulin sensitivity. Insulin sensitivity has typically been assessed by measuring fasting insulin and by glucose tolerance tests.

Sigal et al., [20] investigated the effects of an 8 -week long circuit training program, combining aerobic and resistance exercise, compared with a non-training period. Subjects were randomly allocated a group. Muscular strength increased with training while skin folds, the percentage of body fat and waist: Hip ratio significantly decreased. Concurrently, following training, peak oxygen uptake and exercise test duration increased, with a decrease in $\mathrm{HbA}_{1 \mathrm{c}}$ and fasting blood glucose.
Willey et al., [21] reported that resistive exercises improve insulin sensitivity to about the same extent as aerobic exercise. Also, Casey et al., [22] reported that progressive resistive exercises leads to a small but statistically significant improvement in $\mathrm{HbA}_{1 \mathrm{c}}$ and therefore glycemic control. Th e results are likely to be clinically significant as any improvement in glycemic control that can be achieved safely is considered important.

Shabani et al., [23] reported that the CRT done 3 days/week for 3 months experienced a positive effect on glycemic control in women diagnosed as having diabetes type II, with substantial alterations in $\mathrm{HbA}_{1 \mathrm{c}}$ and reduction of subcutaneous fat being recorded in the CRT group.

Another study showed by Wycherley et al., [24] that 12 weeks progressivemoderate-intensity resistance exercise resulted in significant improvements in glycaemia in Indians with Type II diabetes. This showed that the effectiveness of resistance training on improving $\mathrm{HbA}_{1 \mathrm{c}}$ in diabetes patients appeared to differ according to the intensity, frequency, and duration of training.

Also a study by Church et al., [25] showed that the effect of resistance exercise on glycemic control in individuals associated with a $0.57 \%$ decline in absolute HbA $_{1 \mathrm{c}}$ as compared with control.

\section{References}

1- American Diabetes, Association. (January): Lifestyle Management: Standards of Medical Care in Diabetes2019". Diabetes Care. 42 (Suppl 1): S46-S60, 2019.

2- ZHENG Y., LEY S.H. and HU F.B.: Global aetiology and epidemiology of type 2 diabetes mellitus and its complications. Nature Reviews Endocrinology, 14 (2): 88, 2018.

3- THOMPSON W.R.: Worldwide survey of fitness trends for 2019. ACSM's Health Fitness J., 22: 10-7, 2018.

4- MAILLARD F., PEREIRA B. and BOISSEAU N.: Effect of high-intensity interval training on total, abdominal and visceral fat mass: A meta-analysis. Sports Medicine, 48 (2): 269-88, 2018.

5- JUNG W.S. and PARK H.Y.: Circuit exercise promotes health related factors in sarcopenic obesity elderly: A mini-review. MOJ Gerontology \& Geriatrics, 3 (3): 2336, 2018.

6- American Thoracic Society statement: Guidelines for the six-minute walk test. Am. J. Respir. Crit. Care Med. ATS Committee on Proficiency Standards for Clinical Pulmonary Function Laboratories. Am. J. Respir. Crit. Care Med., 166: 111-7, 2002.

7- DOURADO V.Z., VIDOTTO M.C. and GUERRA R.L.: Reference equations for the performance of healthy adults on field walking tests. J. Bras. Pneumol., 37 (5): 607-14, 2011. 
8- KARVONEN M.J., KENTALA E. and MUSTALO O. The effects of training on heat rate; a longitudinal study. Ann. Med. Exp. Biol. Fenn., 35: 307-15, 1957.

9- TANAKA H., MONAHAN K.D. and SEALS D.R.: Agepredicted maximal heart rate revisited. Journal of the American College of Cardiology, 37: 153-6, 2001.

10- HOOD M.S., LITTLE J.P. and TARNOPOLSKY M.A.: Low-volume interval training improves muscle oxidative capacity in sedentary adults. Medicine \& Science in Sports \& Exercise, 43 (10): 1849-56, 2010.

11- BORG G.: Borg's perceived exertion and pain scales, 1998.

12- JON-KYLE DAVIS and GREEN JAMES MATTHEW: Strength and Conditioning Journal; Lawrence, 2007.

13- American Diabetes Association: Diagnosis and classification of diabetes mellitus. Diabetes care, 37 (Supplement 1), S81-S90, 2014

14- STOA E.M., MELING S., NYHUS L.K., et al.: Highintensity aerobic interval training improves aerobic fitness and $\mathrm{HbA}_{1_{\mathrm{c}}}$ among persons diagnosed with type 2 diabetes. European journal of applied physiology, 117 (3): 455-67, 2017.

15- MITRANUN W., DEEROCHANAWONG C., TANAKA H., et al.: Continuous vs interval training on glycemic control and macro- and microvascular reactivity in type 2 diabetic patients. Scandinavian journal of medicine \& science in sports, 24 (2): e69-e76, 2014.

16- RICHARDS J.C., JOHNSON T.K. and KUZMA J.N.: Short-term sprint interval training increases insulin sensitivity in healthy adults but does not affect the thermogenic response to beta-adrenergic stimulation. The Journal of physiology, 588 (15): 2961-72, 2010.

17- HOOD M.S., LITTLE J.P., TARNOPOLSKY M.A., MYSLIK F. and GIBALA M.J.: Low-volume interval training improves muscle oxidative capacity in sedentary adults.Medicine \& Science in Sports \& Exercise, 43 (10): 1849-56, 2011.
18- SHABAN N., KENNO K. and MILNE K.: The effects of a 2 week modified high intensity interval training program on the homeostatic model of insulin resistance (HOMAIR) in adults with type 2 diabetes. The Journal of sports medicine and physical fitness, 54 (2): 203-9, 2014.

19- BOUTCHER S.H.: High-intensity intermittent exercise and fat loss. Journal of obesity, 2011, 2010.

20- SIGAL R.J., KENNY G.P., BOULE’’ N.G., WELLS G.A., PRUD'HOMME D., FORTIER M., REID R.D., TULLOCH H., COYLE H., PHILLIPS P., JENNINGS A. and JAFFEY J.: Effects of aerobic training, resistance training, or both on glycemic control in Type 2 diabetes. Diabetes: A randomized trial. Ann. Intern. Med., 147: 357-69, 2007.

21- WILLEY K. and FIATARONE-SINGH M.: Battling insulin resistance in elderly obesepeople with type 2 diabetes: Bring on the heavy weights. Diabetes care, 26 (5): 1580-8, 2003.

22- CASEY I. and NICHOLAS F.: Progressive resistance exercise improves glycaemiccontrol in people with type 2 diabetes mellitus: A systematic review. Australian Journal of Physiotherapy, 55 (4): 237-46, 2009.

23- SHABANI R., NAZARI M., DALILI S. and HASSANZADEH A.R.: Effect of circuit resistance training on glycemic control of females with diabetes type II. International journal of preventive medicine, 6, 2015.

24- WYCHERLEY T.P., NOAKES M., CLIFTON P.M., CLEANTHOUS X., KEOGH J.B. and BRINKWORTH G.D.: A high-protein diet with resistance exercise training improves weight loss and body composition in overweight and obese patients with type 2 diabetes. Diabetes care, 33 (5): 969-76, 2010.

25- CHURCH T.S., BLAIR S.N., COCREHAM S., JOHANNSEN N., JOHNSON W., KRAMER K., et al.: Effects of aerobic and resistance training on hemoglobin $A_{1 c}$ levels in patients with type 2 diabetes: A randomized controlled trial. Jama, 304 (20): 2253-62, 2010. 


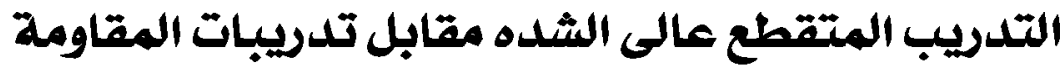

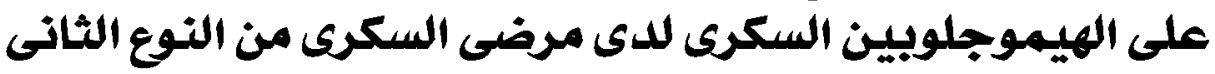

الغرض من هذه الدراسة المقارنة بين تآثير التريب المتقطع عالى الشدة مقابل تدريبات المقاومة على الهيموجلوبين السكرى لدى مرضى

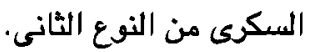

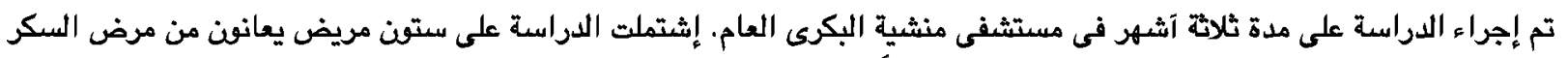

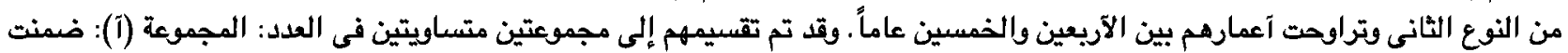

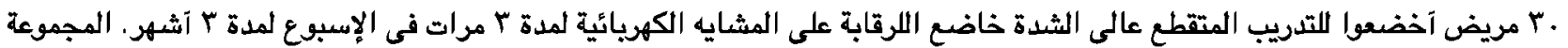

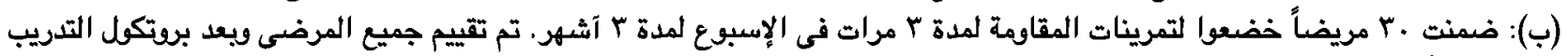

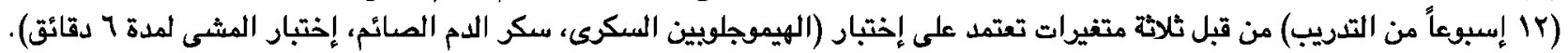

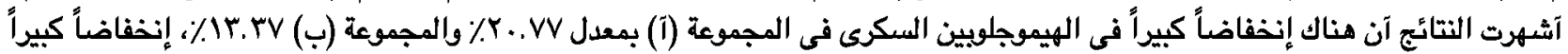

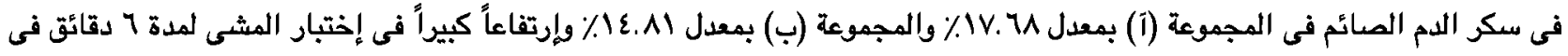

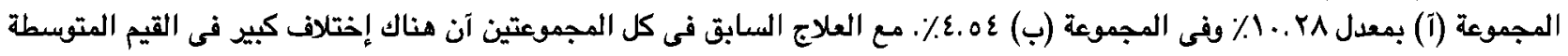

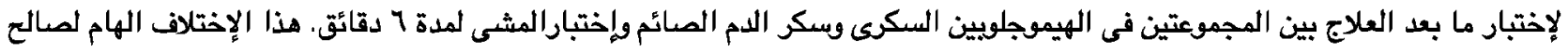

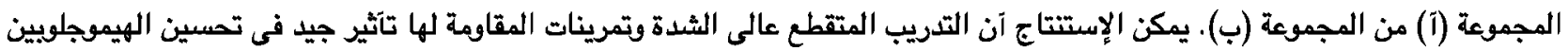

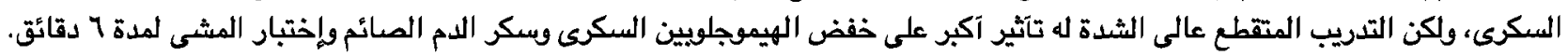

الطريقة: شارك فى هذه الرسالة ستون مريض يعانون من مرض السكر من النوع الثانى وتراوحت أعمارهم بين الآربعين والخمسين عاماً.

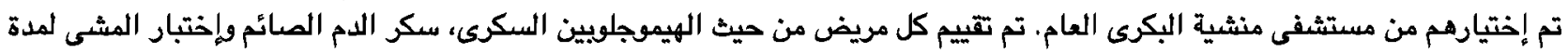
1

الإستتاجات: آثبتت نتائج الدراسة آن التدريب المتقطع عالى الشدة وتدريبات المقاومة لهم تآثير على الهيموجلوبين السكرى، التدريب المتقطع عالى الثدة له تآثير آفضل الثضل. 